\title{
Retrospective Study of Facial Nerve Injury in Temporomandibular Joint Surgeries Following Preauricular Approach \\ Rajasekhar $\mathbf{G}^{1 *}$, Kruthi $\mathbf{N}^{2}$, Nandagopl $\mathbf{V}^{\mathbf{1}}$ and Sudhir $\mathbf{R}^{\mathbf{2}}$
}

${ }^{1}$ Department of Oral and Maxillofacial Surgery, Mamata Dental College and Hospital, India

${ }^{2}$ Karthik Superspeciality Hospital, India

\begin{abstract}
Purpose

The aim of the present study is to evaluate the facial nerve function following surgeries of the temporomandibular joint through preauricular approach, with the objectives of identifying the commonly affected branch of facial nerve and the time taken for resolution of weakness and occurrence of any permanent nerve damage.

\section{Methods}

A retrospective evaluation was done on 32 patients who reported to Mamata Dental College and Hospital, Khammam, India, from July 2010 to June 2013 who underwent various surgical procedures of temporomandibular joint through pre auricular approach. Facial nerve weakness was assessed both at rest and in function through House and Brackman Facial Nerve Grading System (HBFNGS) during 24 hours, 1 week, 1 month, 3 months and 6 months and 1year postoperatively and the results were summarized.

Results

20 out of 32 patients had facial nerve weakness following surgery. $60 \%$ of the patients had recovered normal motor function of facial nerve 1 month postoperatively, $94.44 \%$ have regained normal function 3 months postoperatively. At 1 year post operative period all the patients $(100 \%)$ have regained normal motor nerve function. Temporal and zygomatic branches were involved most commonly. Time taken for resolution of weakness was more for temporal
\end{abstract} branch.

\section{Conclusion}

Facial nerve weakness following preauricular approach is only temporary and most common causes are stretching and compression of the nerve. Preauricular approach is considered safe and cosmetic.

Keywords: Facial nerve; Pre auricular incision; House and Brackman facial nerve grading system; Temporal ; Zygomatic

\section{Introduction}

Facial nerve is considered the "Queen of The Face" as it innervates the muscles of facial expression. Anatomic variations and multiple innervation patterns of the peripheral branches render facial nerve to an increased risk during various surgical procedures to temporomandibular joint using preauricular approach [1]. Facial nerve injury following various surgical procedures to the maxillofacial region ranges from $0-48 \%$ [1]. Incidence of facial nerve injury following TMJ surgeries ranges from 1-32\% [2]. Out of the several methods used for evaluating the motor function of facial nerve, House and Brackman Facial Nerve Grading System (HBFNGS) has gained some importance which was introduced in 1983 and modified by Brackmann in 1985 and accepted by American Academy of Otolaryngology and Head and Neck Surgery [3]. It is a comprehensive method of evaluation of motor function, both at rest and in function. It carries an interobserver reliability of $93 \%$ [3].

Motor impairment of the facial nerve has severe emotional impact on patients both in terms of function and esthetics. We have noticed that there is no proper consensus on the incidence of facial nerve damage and the time taken for the resolution of the symptoms in this part of the country. Hence, the authors have undertaken the following study with the aim to evaluate the facial nerve function following surgery through preauricular incision that would contribute to the previous literature, increase awareness among the surgeons and as well as help them in assuring the patients undergoing surgery in the region of temporomandibular joint. The objectives of the current study are to identify the commonly affected branch of facial nerve, the time taken for resolution of the weakness and incidence of any permanent nerve damage.

\section{Material and Methods}

Retrospective data was collected from a total of 32 patients who reported to Mamata Dental College and Hospital, Khammam, Andhra Pradesh, India, during a period of 3 years from July 2010 to June 2013 who underwent various surgical procedures to temporomandibular joint using preauricular approach (Table1). Ethical clearance was obtained from the institute and informed consent was taken from all the patients. Patients who had facial nerve weakness pre operatively were excluded from the study. Facial nerve weakness post operatively was assessed both at rest and in function through House and Brackman Facial Nerve Grading System (HBFNGS) during 24 hours, 1 week, 1

*Corresponding author: Rajasekhar G, Professor and Head, Department of Oral and Maxillofacial Surgery, Mamata Dental College and Hospital, Khammam, Andhra Pradesh, India, Tel: 91-9000018128; E-mail: maxface2007@gmail.com

Received April 20, 2014; Accepted May 27, 2014; Published May 30, 2014

Citation: Rajasekhar G, Kruthi N, Nandagopl V, Sudhir R (2014) Retrospective Study of Facial Nerve Injury in Temporomandibular Joint Surgeries Following Preauricular Approach. Anaplastology 3: 132. doi: 10.4172/2161-1173.1000132

Copyright: (C) 2014 Rajasekhar $\mathrm{G}$ et al. This is an open-access article distributed under the terms of the Creative Commons Attribution License, which permits unrestricted use, distribution, and reproduction in any medium, provided the original author and source are credited. 
Citation: Rajasekhar G, Kruthi N, Nandagopl V, Sudhir R (2014) Retrospective Study of Facial Nerve Injury in Temporomandibular Joint Surgeries Following Preauricular Approach. Anaplastology 3: 132. doi: 10.4172/2161-1173.1000132

Page 2 of 6

\begin{tabular}{|c|c|c|c|c|}
\hline S.NO & AGE/SEX & DIAGNOSIS & INCISION & BRANCHES AFFECTED \\
\hline 1 & 25YR/M & RT TMJ ANKYLOSIS & ALKAYAT \& BRAMLEY & TEMPORAL \& ZYGOMATIC \\
\hline 2 & 40YR/M & RT CONDYLAR \# & ROWE'S & TEMPORAL \& ZYGOMATIC \\
\hline 3 & $11 \mathrm{YR} / \mathrm{F}$ & RT TMJ ANKYLOSIS & ALKAYAT \& BRAMLEY & TEMPORAL, ZYGOMATIC \\
\hline 4 & 45YR/M & RT TMJ ANKYLOSIS & ALKAYAT \& BRAMLEY & TEMPORAL \& ZYGOMATIC \\
\hline 5 & $32 Y R / M$ & LEFT CONDYLAR \# & ROWE'S & TEMPORAL, ZYGOMATIC \\
\hline 6 & $11 Y R / F$ & LEFT TMJ ANKYLOSIS & ALKAYAT \& BRAMLEY & TEMPORAL, ZYGOMATIC \\
\hline 7 & $26 \mathrm{YR} / \mathrm{F}$ & RT TMJ ANKYLOSIS & ALKAYAT \& BRAMLEY & TEMPORAL, ZYGOMATIC \\
\hline 8 & 55YR/M & BILATERAL TMJ ANKYLOSIS & ALKAYAT \& BRAMLEY & TEMPORAL, ZYGOMATIC \\
\hline 9 & 9YR/M & RT TMJ ANKYLOSIS & ALKAYAT \& BRAMLEY & TEMPORAL, ZYGOMATIC \\
\hline 10 & $25 / M$ & BILATERAL CONDYLAR \# & ROWE'S & TEMPORAL, ZYGOMATIC \\
\hline 11 & 22YR/M & LEFT TMJ ANKYLOSIS & ALKAYAT \& BRAMLEY & TEMPORAL, ZYGOMATIC \\
\hline 12 & 9YR/F & LEFT TMJ ANKYLOSIS & ALKAYAT \& BRAMLEY & TEMPORAL, ZYGOMATIC \\
\hline 13 & 27YR/M & RT CONDYLAR \# & ROWE'S & TEMPORAL \& ZYGOMATIC \\
\hline 14 & 25YR/M & CONDYLAR HYPERPLASIA & ALKAYAT \& BRAMLEY & TEMPORAL, ZYGOMATIC \\
\hline 15 & 29YR/M & LEFT CONDYLAR \# & ROWE'S & TEMPORAL \\
\hline 16 & 19YR/F & LEFT CONDYLAR \# & ROWE'S & TEMPORAL \& ZYGOMATIC \\
\hline 17 & 35YR/M & BILATERAL CONDYLAR \# & ROWE'S & TEMPORAL \\
\hline 18 & 30YR/M & RT CONDYLAR \# & ROWE'S & TEMPORAL, ZYGOMATIC \\
\hline 19 & 27YR/M & RT CONDYLAR \# & ROWE'S & TEMPORAL \\
\hline 20 & $35 Y R / F$ & RT CONDYLAR\# & ROWE'S & TEMPORAL, ZYGOMATIC \\
\hline 21 & $25 Y R / F$ & LEFT CONDYLAR \# & ROWE'S & - \\
\hline 22 & $47 Y R / F$ & LEFT CONDYLAR \# & ROWE'S & - \\
\hline 23 & 19YR/M & RT CONDYLAR \# & ROWE'S & - \\
\hline 24 & $42 Y R / F$ & LEFT CONDYLAR \# & ROWE'S & - \\
\hline 25 & $32 \mathrm{YR} / \mathrm{F}$ & RT CONDYLAR\# & ROWE'S & - \\
\hline 26 & $24 Y R / M$ & LEFT CONDYLAR \# & ROWE'S & - \\
\hline 27 & 33YR/M & RT CONDYLAR \# & ROWE'S & - \\
\hline 28 & $44 \mathrm{YR} / \mathrm{F}$ & BILATERAL CONDYLAR \# & ROWE'S & - \\
\hline 29 & 23YR/M & LEFT CONDYLAR \# & ROWE'S & - \\
\hline 30 & 56YR/M & RT CONDYLAR\# & ROWE'S & - \\
\hline 31 & $21 \mathrm{YR} / \mathrm{F}$ & RT CONDYLAR\# & ROWE'S & - \\
\hline 32 & 19YR/F & LEFT CONDYLAR \# & ROWE'S & - \\
\hline
\end{tabular}

Shows number of patients included in the study, with their demographic data of age, sex, diagnosis, incision given and the facial nerve branch / branches affected

Table 1: List of the Patients Included In the Study

month, 3 months and 6 months and lyear postoperatively (Table 2). Statistical analysis was done by Friedman Test and Wilcoxon Signed Ranks test using SPSS software version 17.0.

All the patients were photographed in the following positions: at rest, while closing the eyes with minimal effort, while trying to close the eyes with maximum effort, raising the eyebrows, blowing the cheeks and smiling or showing the lower anterior teeth and the results were summarized. When both temporal and zygomatic branches were involved, grading was given based on the ability to close the eye.

\section{Results}

Out of the 32 patients, 9 patients were diagnosed to have temporomandibular joint ankylosis, of which bilateral ankylosis was seen in case 1 . There were 22 cases of condylar fracture in which 3 cases had bilateral involvement of fracture and one case of condylar hyperplasia was also included. A total of 36 surgical approaches were carried out on 32 patients with modifications of pre auricular incisions of which, Al-Kayat and Bramley incision was given in 10 cases, Rowe's incision in 22 cases.

In a total of 32 patients, $20(62.5 \%)$ had facial nerve weakness following surgery. During first 24 hours following the surgery, 10 out of 20 patients $(50 \%)$ showed moderately severe dysfunction while 6 patients (30\%) showed moderate dysfunction and 4 patients $(20 \%)$ had mild dysfunction of the facial nerve. The results are summarized in Table 2. At $1^{\text {st }}$ month post operative period, 12 out of 20 patients (60\%) had recovered normal motor function of facial nerve. Two patients could not be reviewed for more than 1 month post operatively as they did not turn up for further follow up, thus attiring the sample size to $18(\mathrm{n}=18)$ at 3 months post operative period, and on follow up after 3 months 17 patients out of 18 (94.44\%) regained normal facial nerve function and at 6 months post operative period all except one patient regained motor function while the remaining 1 patient had mild temporal branch weakness without affecting the function of closure of the eye. At $1^{\text {st }}$ year post operative period, all the 18 patients $(100 \%)$ recovered normal motor function. 
Citation: Rajasekhar G, Kruthi N, Nandagopl V, Sudhir R (2014) Retrospective Study of Facial Nerve Injury in Temporomandibular Joint Surgeries Following Preauricular Approach. Anaplastology 3: 132. doi: 10.4172/2161-1173.1000132

Page 3 of 6

\begin{tabular}{|c|c|c|c|c|c|c|}
\hline CASE & 24 HRS & I WEEK & 1 MONTH & 3 MONTHS & 6 MONTHS & 1 YEAR \\
\hline 1 & GRADE IV & GRADE IV & GRADE III & GRADE II & GRADE I & GRADE I \\
\hline 2 & GRADE II & GRADE II & GRADE I & GRADE I & GRADE I & GRADE I \\
\hline 3 & GRADE IV & GRADE III & GRADE II & GRADE I & GRADE I & GRADE I \\
\hline 4 & GRADE IV & GRADE III & GRADE II & GRADE I & GRADE I & GRADE I \\
\hline 5 & GRADE II & GRADE II & GRADE I & GRADE I & GRADEI & GRADE I \\
\hline 6 & GRADE IV & GRADE III & GRADE I & GRADE I & GRADE I & GRADE I \\
\hline 7 & GRADE IV & GRADE II & GRADE I & GRADE I & GRADE I & GRADE I \\
\hline 8 & GRADE IV & GRADEIV & GRADE III & GRADEI & GRADE I & GRADE I \\
\hline 9 & GRADE IV & GRADE IV & GRADE III & GRADE I & GRADE I & GRADE I \\
\hline 10 & GRADE III & GRADE III & GRADE II & GRADE I & GRADE I & GRADE I \\
\hline 11 & GRADE IV & GRADE IV & GRADE II & GRADE I & GRADE I & GRADE I \\
\hline 12 & GRADE IV & GRADE IV & GRADE IV & - & - & - \\
\hline 13 & GRADE III & GRADE II & GRADE I & GRADE I & GRADE I & GRADE I \\
\hline 14 & GRADE III & GRADE II & GRADE I & GRADE I & GRADE I & GRADE I \\
\hline 15 & GRADE III & GRADE II & GRADE I & GRADE I & GRADE II & GRADE I \\
\hline 16 & GRADE II & GRADE II & GRADE I & - & - & - \\
\hline 17 & GRADE IV & GRADE III & GRADE I & GRADE I & GRADE I & GRADE I \\
\hline 18 & GRADE III & GRADE II & GRADE I & GRADE I & GRADE I & GRADE I \\
\hline 19 & GRADE III & GRADE II & GRADE I & GRADE I & GRADE I & GRADE I \\
\hline 20 & GRADE II & GRADE II & GRADE I & GRADE I & GRADE I & GRADE I \\
\hline
\end{tabular}

Facial nerve weakness following surgery of all the 20 patients included in the study during 24 hours, 1 week, 1 month, 3 months, 6 months and 1 year post operatively according to House \& Brackmann Facial Nerve Grading System

Table 2: Facial Nerve Weakness According To Hbfngs

\begin{tabular}{|c|c|}
\hline Grade & Characteristics \\
\hline I. Normal & Normal function in all areas \\
\hline II. Mild dysfunction & $\begin{array}{l}\text { Gross: slight weakness noticeable only on close inspection } \\
\text { No synkinesis, contracture, or hemifacial spasm } \\
\text { At rest: normal asymmetry and tone } \\
\text { Motion: } \\
\text { Forehead: some to normal movement } \\
\text { Eye: completenclosure with minimal effort \& slight asymmetry }\end{array}$ \\
\hline III. Moderate dysfunction & $\begin{array}{l}\text { Gross: obvious but not disfiguring difference between two sides. Noticeable but } \\
\text { not severe synkinesis, contracture and/or hemifacial spasm. } \\
\text { At rest: normal symmetry \& tone } \\
\text { Motion: } \\
\text { Forehead: slight to no movement } \\
\text { Eyes: total closure with maximum effort } \\
\text { Mouth: movement of the corner of the mouth with maximal effort \& obvious } \\
\text { asymmetry }\end{array}$ \\
\hline IV. Moderately severe dysfunction & $\begin{array}{l}\text { Gross : obvious weakness and/or disfiguring asymmetry } \\
\text { At rest: normal muscle \& tone } \\
\text { Motion: Forehead: no movement } \\
\text { Eyes: incomplete closure with maximum effort } \\
\text { Mouth: asymmetry at maximum effort }\end{array}$ \\
\hline V. Severe dysfunction & $\begin{array}{l}\text { Gross: only barely perceptible motion } \\
\text { At rest : asymmetry with droop of corner of mouth. Decreased or absent naso } \\
\text { labial fold } \\
\text { Motion: } \\
\text { Forehead: No movement } \\
\text { Eyes: incomplete closure with significant movement of eyelid with maximum } \\
\text { effort } \\
\text { Mouth: slight movement of the corner of the mouth }\end{array}$ \\
\hline VI. Total paralysis & $\begin{array}{l}\text { Loss of tone } \\
\text { Asymmetry } \\
\text { No movement }\end{array}$ \\
\hline
\end{tabular}

House \& Brackmann Facial Nerve Grading System (HBFNGS)

Table 3: House and Brackmann Facial Nerve Grading System 
Citation: Rajasekhar G, Kruthi N, Nandagopl V, Sudhir R (2014) Retrospective Study of Facial Nerve Injury in Temporomandibular Joint Surgeries Following Preauricular Approach. Anaplastology 3: 132. doi: 10.4172/2161-1173.1000132

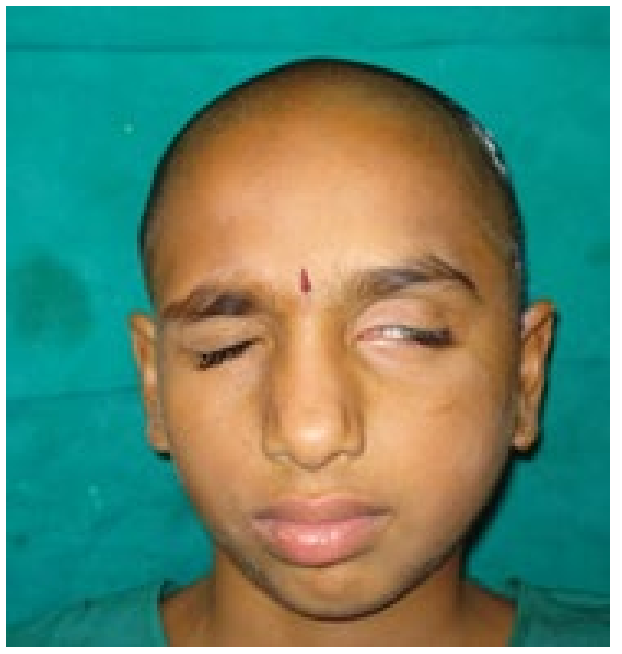

Figure1: Zygomatic branch affected on left side

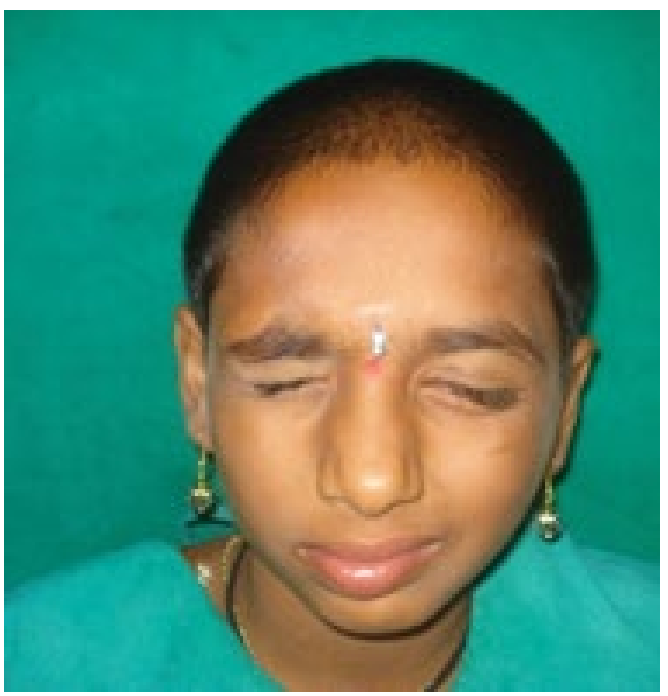

Figure 2: Recovery following 1 month

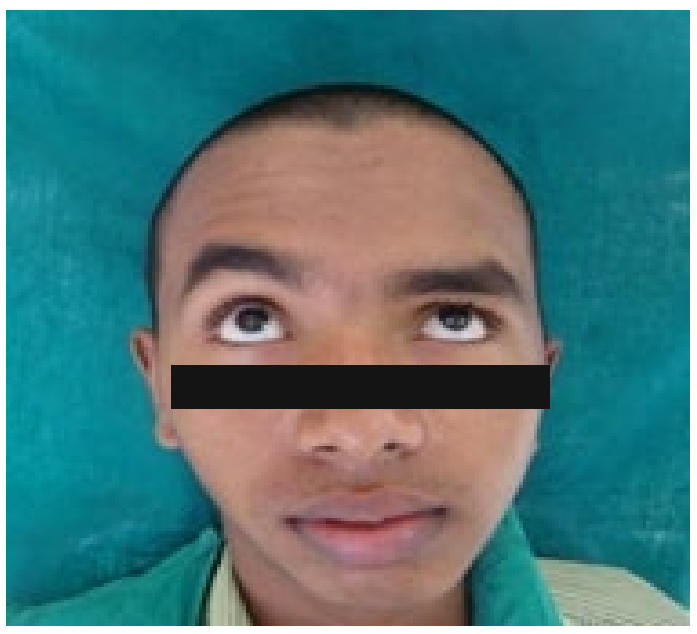

Figure 3: Temporal branch affected (left side)

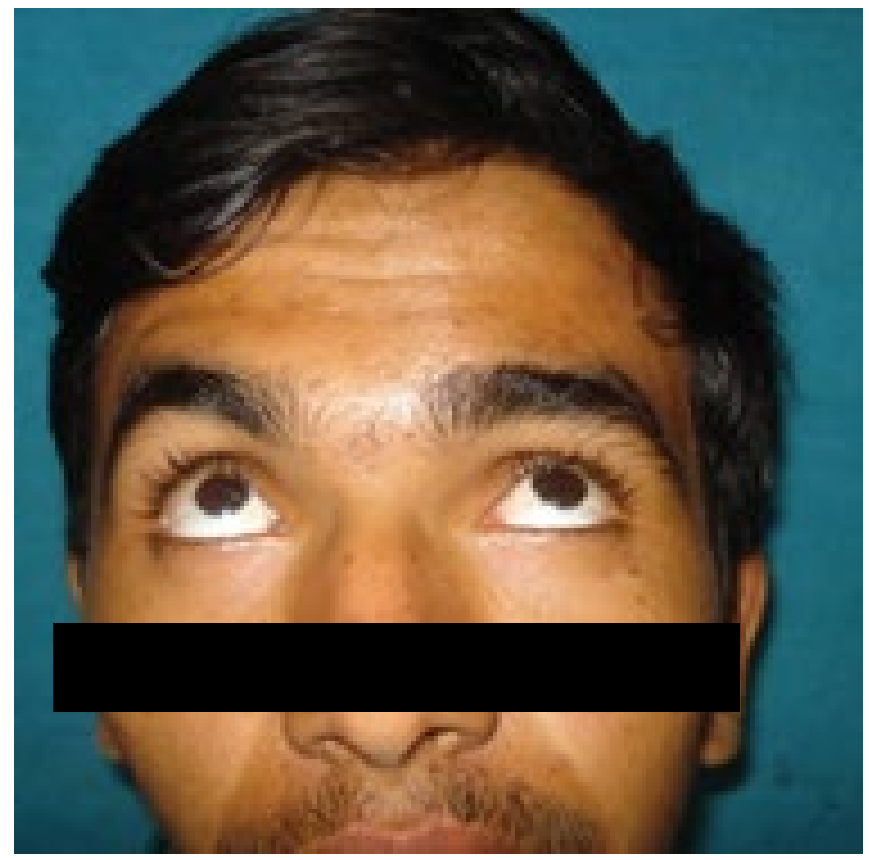

Figure 4: Recovery 3 months

Maximum amount of recovery occurred in 1-3 months following surgery and also a significant improvement in motor nerve function is seen over time as depicted in Table 4 and 5 shows statistical analysis using Friedman test and Wilcoxon signed ranks test. None of the patients had permanent facial nerve weakness.

Out of 20 patients, in 17 cases (85\%) both temporal and zygomatic branches were involved, only temporal branch was involved in 3 cases (15\%). None of the patients had moderate dysfunction after 3 months following surgery. Only temporal and zygomatic branches were involved and average time taken for the complete resolution of weakness was more for temporal branch. In 4 cases, where both temporal and zygomatic branches were involved, grading was given based on the ability to close the eye, though they were considered Grade I, there was mild to moderate weakness of the temporal branch. However, none of the patients had a permanent damage to the facial nerve.

\section{Discussion}

Weinberg and Kryshtalskyj [4], in their review of the literature stated that incidence ranged from $1 \%$ to $55 \%$ among different authors. In the present study 20 patients $(62.5 \%)$ had facial nerve weakness following surgery. Incidence of the motor function impairment following surgery varied among various authors [5]

Age or gender did not show any significant difference in time taken for recovery, only surgical procedure has influenced the recovery, as delayed recovery was encountered in patients who have undergone extensive surgeries like interposition alarthroplasty (Grade III and Grade II 1 month post operatively) compared to those who underwent internal fixation of condylar fractures and gap arthroplasty (Grade I, 1 month post operatively). These results are comparable to those reported by Nogueir et al. [5]. 94\% recover normal function 6 months postoperatively while $100 \%$ of the patients recovered normal function 1 year postoperatively (Figure 1-4). 


\begin{tabular}{|c|c|c|c|c|c|c|}
\hline Grade (HBFNGS) & $24 \mathrm{hrs}$ & 1 week & 1 month & 3 month & 6 month & 1 year \\
\hline Grade I & - & - & 12 & 17 & 17 & 18 \\
\hline Grade II & 4 & 10 & 4 & 1 & 1 & - \\
\hline Grade III & 6 & 5 & 3 & - & - & - \\
\hline Grade IV & 10 & 5 & 1 & - & - & - \\
\hline Total & 20 & 20 & 20 & 18 & 18 & 18 \\
\hline Mean \pm SD & $3.30 \pm 0.80$ & $2.75 \pm 0.85$ & $1.65 \pm 0.93$ & $1.06 \pm 0.24$ & $1.06 \pm 0.24$ & $1.00 \pm 0.00$ \\
\hline Median & 3.50 & 2.50 & 1.00 & 1.00 & 1.00 & 1.00 \\
\hline Mean Rank ${ }^{\#}$ & 5.78 & 5.19 & 3.06 & 2.33 & 2.39 & 2.25 \\
\hline
\end{tabular}

comparison of improvement in motor function of the nerve as the time progressed using Friedman Test: ( $p<0.001$; highly significant) that shows a significant improvement in $1^{\text {st }} \& 3^{\text {rd }}$ months following surgery.

Table 4: Showing Statistical Analysis Using Friedman Test

\begin{tabular}{|c|c|c|c|c|c|}
\hline Time Point & Grade Decreased & Grade Increased & Remained Same & Z value" & $P$ value \\
\hline $24 \mathrm{hrs}-1$ week & 10 & - & 10 & 3.051 & $0.002^{*}$ \\
\hline 24 hrs - 1 month & 19 & - & 1 & 3.891 & $<0.001^{*}$ \\
\hline $24 \mathrm{hrs}-3$ month & 18 & - & - & 3.789 & $<0.001^{*}$ \\
\hline $24 \mathrm{hrs}-6$ month & 18 & - & - & 3.792 & $<0.001^{*}$ \\
\hline 24 hrs -1 year & 18 & - & - & 3.796 & $<0.001^{*}$ \\
\hline 1 week - 1 month & 19 & - & 1 & 4.119 & $<0.001^{*}$ \\
\hline 1 week -3 month & 18 & - & - & 3.796 & $<0.001^{*}$ \\
\hline 1 week - 6 month & 17 & - & 1 & 3.681 & $<0.001^{*}$ \\
\hline 1 week - 1 year & 18 & - & - & 3.792 & $<0.001^{*}$ \\
\hline 1 month - 3 month & 7 & - & 11 & 2.460 & $0.014^{*}$ \\
\hline 1 month - 6 month & 7 & 1 & 10 & 2.165 & $0.030^{*}$ \\
\hline 1 month - 1 year & 7 & - & 11 & 2.428 & $0.015^{*}$ \\
\hline 3 month -6 month & 1 & 1 & 16 & 0.000 & $1.000^{\mathrm{NS}}$ \\
\hline 3 month - 1 year & 1 & - & 17 & 1.000 & $0.317^{\mathrm{NS}}$ \\
\hline 6 month - 1 year & 1 & - & 17 & 1.000 & $0.317^{\mathrm{NS}}$ \\
\hline
\end{tabular}

Wilcoxon Signed Ranks Test: (NS: $p>0.05$; Not Significant; * $p<0.05$; Significant) comparison of improvement in motor function in 24 hrs, 1 week, 1 month, 3 months, 6 months and 1 year to all the other variables that shows significant improvement occurred in 1-3 months.

Table 5: Showing Statistical Analysis Using Wilcoxon Signed Ranks

Wilson et al. [6] stated that preauricular approach often causes injury to the temporal and zygomatic branches. Similar finding was noticed in the present study as well.

We have used House and Brackmann facial nerve grading system for evaluation. Despite the wide acceptance of HBFNGS and its clinical implications, we have experienced its limitations, as $85 \%$ of our patients had involvement of more than one branch with varying degrees of severity. When both temporal and zygomatic branches were involved, grading was given based on the ability to close the eye, as previously described by other authors $[1,2]$.

The time taken for the recovery of motor function ranged between 1-6 months among various authors $[2,6]$. In the present study, maximum amount of recovery occurred at 1-3 months and in 6 months postoperative period all the patients showed recovery of normal motor nerve function except one, who had involvement of only temporal branch which affected neither function nor esthetics and on 1 year follow up, complete recovery of normal function was observed. Thus, permanent damage to the nerve occurred in none of the patients. These findings are in consistence with previous authors who stated that pre auricular approach is safe, cosmetic and results in temporary impairment of function $[2,4,6,7]$.
The time taken for recovery of temporal branch was more compared to zygomatic branch. Cormack et al. [8] have reported 8 types of facial nerve branching patterns after their study on 100 cadaver dissections of which there are multiple anastomoses between the branches. The incidence of cross anstomosis between zygomatic and buccal branches is high (87-100\%) [6]. Temporal branch lies about $2 \mathrm{~cm}$ on average $(0.8$ $3.5 \mathrm{~cm}$ ) from anterior concavity of external auditory canal and crosses zygomatic arch from $2.5-3.5 \mathrm{~cm}$ from lateral orbital rim [2,9]. It lies deep to the temporoparietal fascia and at the zygomatic arch it lies in a condensation of superficial fascia, temporalis fascia and periosteum, and is most vulnerable in this region. If the tissue dissection violates the integrity of this region, it results in temporal nerve weakness. Stretching of the nerve and excessive retraction of the tissues resulting in edema and compression of the nerve might be the possible reasons for the delayed recovery of the temporal branch in our series. However, a larger sample size is needed to draw further conclusions.

\section{Conclusion}

Facial nerve weakness has severe emotional impact on patients. Every attempt should be made to preserve the facial nerve intra operatively as it is associated with morbidity both in terms of 
Citation: Rajasekhar G, Kruthi N, Nandagopl V, Sudhir R (2014) Retrospective Study of Facial Nerve Injury in Temporomandibular Joint Surgeries Following Preauricular Approach. Anaplastology 3: 132. doi: 10.4172/2161-1173.1000132

function and esthetics. From the present study, it can be concluded that neurosensory disturbances following pre auricular incisions are mainly due to stretching of the nerve and compression following edema and are only temporary in nature with maximum amount of recovery occurring between 1-3 months. Hence the patients with postoperative nerve injury must be reassured. The time taken for recovery is more for temporal branch. These motor disturbances can be reduced by minimizing the operating time and with meticulous soft tissue handling.

\section{References}

1. Prabhu RK, Sinha R, Chowdhury SK, Chattopadhyay PK (2012) Evaluation of facial nerve function following surgical approaches for maxillofacial trauma. Ann Maxillofac Surg 2: 36-40.

2. do Egito Vasconcelos BC, Bessa-Nogueira RV, da Silva LC (2007) Prospective study of facial nerve function after surgical procedures for the treatment of temporomandibular pathology. J Oral Maxillofac Surg 65: 972 978.
3. House JW, Brackmann DE (1985) Facial Nerve Grading System. Otolaryngol Head Neck Surg 93:146-147.

4. Weinberg S, Kryshtalskyj B (1992) Facial nerve function following temporomandibular joint surgery using the preauricular approach. J Oral Maxillofac Surg 50: 1048-1051.

5. Nogueira RV, Vasconcelos BC (2007) Facial nerve injury following surgery for the treatment of ankylosis of the temporomandibular joint. Med Oral Patol Oral Cir Bucal 12: 160-165.

6. Wilson AW, Ethunandan M, Brennan PA (2005) Transmasseteric anteroparotid approach for open reduction and internal fixation of condylar fractures. $\mathrm{Br} J$ Oral Maxillofac Surg 43: 57-60.

7. Politi M, Toro C, Cian R, Costa F, Robiony M (2004) The deep subfascial approach to the temporomandibular joint. J Oral Maxillofac Surg 62: 10971102.

8. Henry Hollinshead W (1982) Anatomy for Surgeons. Philadelphia, Harper \& Row, 314-315.

9. Al-Kayat A, Bramley P (1979) Modified pre-auricular approach to the temporomandibular joint and malar arch. Br J Oral Surg 17: 91-103. 